gPR:M

Genual Profesi Kesehatan Masyarakat

http://jurnal.bhmm.ac.id/index.php/jpkm

Corresponding Author.

email address : nurhalinasari@malahayati.ac.id

Received : 27 Juni 2021 Revised : 12 September 2021 Accepted : 1 Oktober 2021

\title{
Perbandingan Ketahanan Hidup Pasien Hemodialisis dengan Komorbid Hipertensi Tahun 2018
}

\author{
$\llbracket$ Nurhalina Sari, Nova Muhani, Dias Dumaika, Aprizal Hendardi \\ Fakultas Kesehatan Masyarakat Universitas Malahayati, Bandar Lampung, Indonesia
}

\begin{abstract}
ABSTRAK
Keberadaan pasien hemodialisis adalah akibat dari meningkatnya kasus penyakit ginjal kronis (PGK). Hipertensi menjadi salah satu faktor utama yang bisa mempercepat penurunan kualitas hidup penderita PGK. Diketahui rerata dan hubungan ketahanan hidup pasien hemodialisis dengan komorbid hipertensi di Rumah Sakit Abdoel Moeloek, Lampung. Penelitian menggunakan desain kohort retrospektif. Sumber data berasal dari dokumen rekam medis pasien hemodialisis di Rumah Sakit Abdoel Moeloek selama tahun 2018. Analisis data menggunakan kaplan meier dan regresi cox. Distribusi frekuensi menunjukkan sebanyak 283 (79.9\%) orang yang mengalami hipertensi. Proporsi kelompok hipertensi yang meninggal sebanyak 147 (51.9\%) orang. Rerata ketahanan hidup kelompok hipertensi adalah 38 bulan, sedangkan pada kelompok non-hipertensi adalah 47 bulan. Hasil uji regresi cox menunjukkan nilai p-value sebesar 0.033 dan hazard rasio 1.5 (95\% interval kepercayaan 1.0-2.2). Rerata lama hidup pasien hemodialisis pada kelompok hipertensi lebih pendek dibandingkan kelompok nonhipertensi. Kelompok hipertensi memiliki risiko ketahanan hidup 1.5 kali lebih besar untuk mengalami kematian dibandingkan kelompok non-hipertensi pada pasien hemodialisis. Kesadaran untuk rutin mengukur tekanan darah dan melakukan deteksi dini hipertensi sangat dianjurkan melalui pemanfaatan program Posbindu (Pos Pelayanan Terpadu) di Puskemas dan mengoptimalkan sosialisasi program Germas (Gerakan Masyarakat Hidup Sehat) kepada masyarakat melalui berbagai media.
\end{abstract}

Kata kunci: Hemodialisis, Hipertensi, Ketahanan hidup

Comparison of Survival of Hemodialysis Patients with Comorbid Hypertension in 2018

\begin{abstract}
The presence of hemodialysis patients is one of the consequences of increasing chronic kidney disease (CKD). Hypertension is one of the main factors that can accelerate the decline in patients' quality of life with CKD. The study was aimed to determine the mean and hazard survival of hemodialysis patients with comorbid hypertension at the Abdoel Moeloek Hospital in Lampung. This study used a retrospective cohort design. The data was sourced from hemodialysis patients' medical record documents at the Abdoel Moeloek Hospital during 2018. The data collected were 354 people. Data was analyzed Kaplan Meier and Cox regression. The frequency distribution showed that 283 (79.9\%) people had hypertension. The proportion of the hypertensive group who died was 147 (51.9\%). The mean survival period for the hypertensive group was 38 months, while the non-hypertensive group was 47 months. The cox regression test results show a p-value of 0.033 and a hazard ratio of $1.5(95 \%$ confidence interval 1.0-2.2). The mean length of life of CKD patients in the hypertension group was shorter than the non-hypertensive group. The hypertensive group had a 1.5 times greater survival risk of dying than the nonhypertensive group. Awareness to regularly measure blood pressure and perform early detection of hypertension is highly recommended. Early detection can be done by utilizing the Posbindu (Integrated Service Post) program in Primary Healthcare and optimizing the socialization of the Germas (Healthy Living Community Movement) program to the public through various media.
\end{abstract}

Kata kunci: Hemodialysis, Hypertension, Survival of Life.

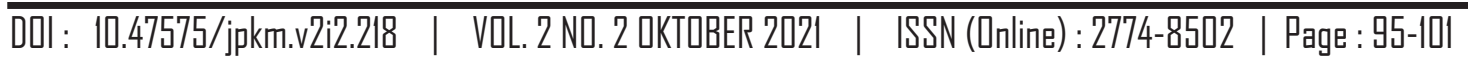




\section{PENDAHULUAN}

Organisasi Kesehatan Dunia (WHO) menyatakan perkembangan kasus kesakitan dan kematian yang diakibatkan oleh Penyakit Ginjal Kronis (PGK) terus meningkat setiap tahunnya. Dalam laporan the Global Burden of Disease pada tahun 2017 menyebutkan PGK adalah penyebab kematian yang terus meningkat menjadi urutan ke-15 pada tahun 2017(Stanaway et al., 2018). Laporan yang sama menyebutkan sekitar 2 juta lebih penduduk dunia mendapatkan perawatan dialisis bahkan menjalani transplantasi ginjal. Saat ini telah tercatat sekitar $10 \%$ penduduk di seluruh dunia mengalami PGK dan jutaan orang meninggal setiap tahun karena ketiadaan akses pengobatan. Kementerian Kesehatan Indonesia juga melaporkan bahwa dari total populasi Indonesia yang berjumlah 258 juta jiwa, 73\% kematian disebabkan oleh Penyakit Tidak Menular (PTM) dan 27\% diantaranya berisiko mengalami kematian dini. Salah satu penyumbang kematian dari PTM adalah penyakit ginjal kronik dengan komorbid hipertensi (Moeloek, 2018).

Perkembangan PGK di Indonesia tercatat memiliki prevalensi sebesar dua persen berdasarkan laporan Riskesdas 2013 (Badan Penelitian dan Pengembangan Kesehatan, 2013). Penyakit Ginjal Kronis (PGK) ini berefek pada beban pembiayaan kesehatan tinggi yang telah mencapai hingga trilyunan rupiah (Moeloek, 2018). Faktor risiko atau komorbid penyakit ginjal kronik tertinggi adalah hipertensi dan diabetes mellitus (Indonesian Renal Registry Team, 2015, 2017; Indonesia Renal Registry Team, 2016; Lydia and Nugroho, 2018). Berdasarkan laporan rutin yang dipublikasikan oleh Indonesian Renal Registry (IRR) tercatat PGK dengan penyakit penyerta hipertensi sebesar $50 \%$ pada tahun 2016, kemudian naik menjadi 51\% dan stagnan hingga tahun 2018 (Indonesian Renal Registry Team, 2015, 2017, 2018; Indonesia Renal Registry Team, 2016). Pada laporan yang sama terlihat PGK dengan hipertensi selalu menduduki peringkat pertama sebagai penyakit penyerta atau komorbid pasien. Beberapa penelitian juga menyebutkan bahwa terdapat hubungan antara hipertensi dengan kejadian PGK pada pasien yang menjalani hemodialisis
(Fitrianto, Azmi and Kadri, 2014; Yulianto, Basuki and Widodo, 2017). Semakin lama seseorang menderita hipertensi maka risiko untuk PGK semakin besar.

Peneliti tertarik untuk mengetahui lebih lanjut mengenai lama hidup dari pasien PGK yang telah menjalani hemodialisis dengan komorbid hipertensi. Berdasarkan hal yang telah dikemukakan di atas, peneliti ingin mengetahui rerata lama hidup dan hubungan antara ketahanan hidup pasien hemodialisis dengan komorbid hipertensi di Rumah Sakit Abdoel Moeloek, Lampung pada Tahun 2018.

\section{METODE PENELITIAN}

Penelitian ini menggunakan desain penelitian kohort retrospektif. Populasi penelitian adalah pasien yang menjalani hemodialisis di Rumah Sakit Abdoel Moeloek, sedangkan sampelnya adalah pasien hemodialisis yang tercatat sejak tanggal 01 Januari hingga 31 Desember 2018. Besar sampel minimal dihitung menggunakan rumus uji survival dari Lwanga dan Lemeshow (Ogston et al., 1990) dengan kemaknaan $95 \%(\alpha=\%)$, kekuatan $80 \%$ $(\beta=20 \%)$, dan rasio hazard pasien PGK dengan komorbid hipertensi sebesar 3.02 (Ding et al., 2018), sehingga didapatkan jumlah minimal responden adalah 13. Sampel penelitian yang berhasil dikumpulkan sebanyak 354 pasien hemodialisis. Kriteria inklusi adalah pasien terdiagnosis utama PGK, usia $>18$ tahun, menjalani hemodialisis, memiliki hasil laboratorium fungsi ginjal (kreatin), dan catatan tekanan darah.

\section{HASIL DAN PEMBAHASAN}

Pasien hemodialisis pada penelitian ini lebih banyak dialami pada laki-laki sebanyak 55.4\%, memiliki riwayat komorbid hipertensi $9.9 \%$, dan status pasien meninggal saat menjalani hemodialisis $50.6 \%$ (Tabel 1). Rerata usia pasien hemodialisis berusia 51 tahun dengan usia termuda 19 tahun dan tertua 82 tahun. Pasien rerata telah menjalani proses cuci darah selama 14 bulan dengan pasien terlama 10.5 tahun atau 126 bulan. Pada kelompok hipertensi, kematian responden terbanyak pada laki-laki 56.9\% dan usia diatas 35 tahun 53.8\% (Gambar 1). 
Tabel 1

Karakteristik Pasien

\begin{tabular}{lll}
\hline Variabel & Kategori & $\mathrm{n}($ persen$)$ \\
\hline Tekanan darah & Non-hipertensi & $71(20.1)$ \\
& Hipertensi & $283(79.9)$ \\
Jenis kelamin & Perempuan & $158(44.6)$ \\
& Laki-laki & $196(55.4)$ \\
Usia & $<35$ tahun & $30(8.5)$ \\
& $\geq 35$ tahun & $324(91.5)$ \\
Status pasien & Hidup & $175(49.4)$ \\
& Meninggal & $179(50.6)$ \\
\hline
\end{tabular}

Sumber: Data Diolah
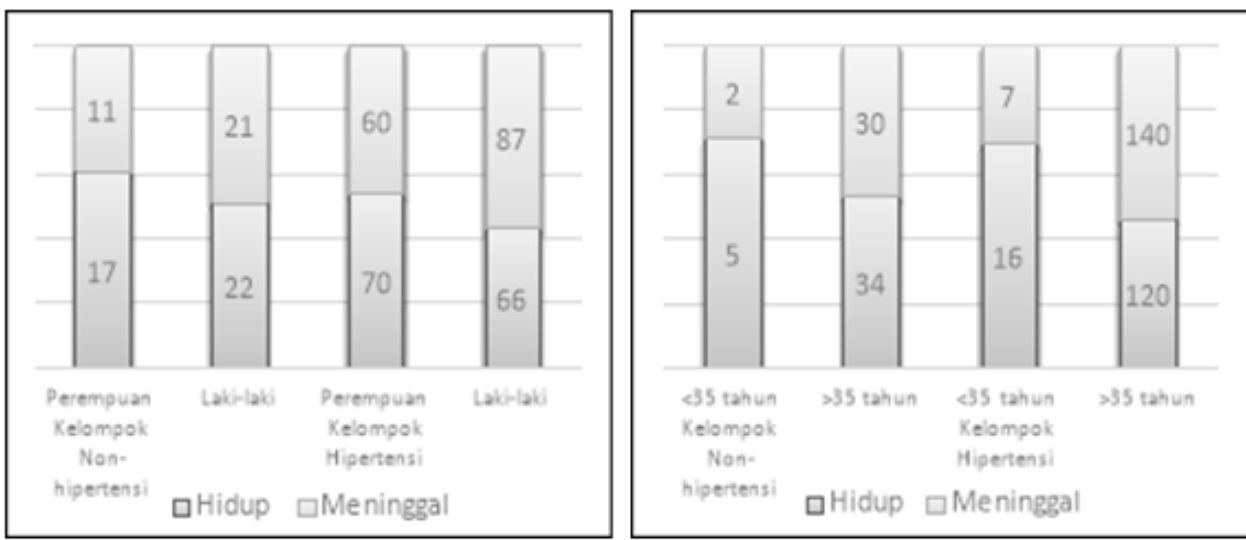

Sumber: Data Diolah

Gambar 1

Distribusi Frekuensi Karakteristik Responden Berdasarkan Kelompok

Proporsi pasien hemodialisis yang memiliki riwayat hipertensi dan kemudian meninggal berjumlah 147 orang (57.5\%). Grafik kaplan meier di atas menunjukkan rerata ketahanan hidup kelompok hipertensi, yaitu 38 bulan lebih pendek dibandingkan dengan kelompok non-hipertensi, yaitu 47 bulan (Gambar 2). Nilai p-value didapatkan sebesar $0.032(\alpha=5 \%)$, nilai ini secara statistik menunjukkan adanya hubungan lama waktu ketahanan hidup pasien hemodialisis antara kelompok hipertensi dengan non-hipertensi. Hasil analisis regresi cox multivariat menunjukkan kelompok hipertensi memiliki risiko 1.5 kali lebih besar untuk mengalami kematian dibandingkan kelompok nonhipertensi pada 95\% interval kepercayaan sebesar $1.1-2.3$ setelah dikontrol oleh variabel umur. Jika dibandingkan dengan variabel umur, maka kelompok usia lebih dari sama dengan 35 tahun memiliki risiko 2.1 kali lebih besar untuk mengalami kematian dibandingkan kelompok umur kurang dari 35 tahun pada $95 \%$ interval kepercayaan sebesar 1.1 - 24.2 setelah dikontrol oleh variabel tekanan darah.

Penyakit ginjal kronis (PGK) didefinisikan sebagai proses penurunan progresif fungsi ginjal yang dapat terjadi dalam beberapa bulan bahkan tahun. Secara fisiologis, penyakit ini adalah kerusakan ginjal dan/atau hingga penurunan Glomerular Filtration Rate (GFR) dengan nilai kurang dari $60 \mathrm{~mL} / \mathrm{min} / 1,73 \mathrm{~m}$ selama minimal 3 bulan lamanya (KDIGO, 2013). Laporan terakhir yang dirilis oleh Registrasi IRR (Indonesian Renal Registry) tahun 2018, diagnosis penyakit utama pasien hemodialisis di Indonesia berasal dari gagal ginjal akut (GGA) 8\%, gagal ginjal kronik (GGK/PGK) 90\%, dan GGA pada PGK 2\%. Pasien PGK lebih banyak didapati pada kondisi 
penyakit penyerta atau komorbid dengan hipertensi (51\%) dan diabetes mellitus (21\%) (Indonesian Renal Registry Team, 2018).

Pada penelitian ini diketahui proporsi pasien hemodialisis yang meninggal karena komorbid hipertensi lebih besar dibandingkan dengan non-hipertensi. Pada penelitian lain yang menganalisis pada komorbid diabetes mellitus (DM) juga didapatkan hasil yang sama bahwa kematian lebih banyak terjadi pada pasien hemodialisis dengan komorbid DM (Muhani and Sari, 2020). Riskesdas 2018 menyebutkan bahwa faktor risiko PGK di Indonesia didominasi oleh hipertensi dengan prevalensi sebesar $25 \%$, obesitas $15.4 \%$, dan diabetes melitus 2.3\% (Badan Penelitian dan Pengembangan Kesehatan, 2018). Hipertensi dan diabetes mellitus masih merupakan komorbid tertinggi. Terkait komorbid hipertensi dapat dijelaskan bahwa apapun penyakit dasar yang telah diderita oleh pasien, bila sudah mengalami PGK dan menjalani hemodialisis maka kontrol tekanan darah pun akan terganggu (Gambar 3) (Badan Penelitian dan Pengembangan Kesehatan, 2013; Indonesian Renal Registry Team, 2015, 2016, 2017, 2018; Moeloek, 2018).

Penelitian lainnya menyebutkan bahwa adanya hubungan signifikan antara tekanan darah dengan kualitas hidup pasien PGK yang menjalani hemodialisis (Nurcahyati, 2011; Delima et al., 2017). Hasil ini diperkuat dari beberapa penelitian yang juga menyatakan bahwa pasien PGK yang menjalani hemodialisis dengan komorbid hipertensi memiliki ketahanan hidup lebih rendah jika dibandingkan dengan pasien yang tidak memiliki riwayat penyakit apapun (Pongsibidang, 2016; Yulianto et al., 2017; Ebad, 2018). Peluang risiko ketahanan hidup pasien hemodialisis dengan komorbid hipertensi semakin lama akan semakin kecil. Menurut teori, penyakit hipertensi yang

Tabel 2

Regresi Cox Ketahanan Hidup Pasien Hemodialisis

\begin{tabular}{lccc}
\hline Variabel & p-value & Hazard rasio & 95\% Interval Kepercayaan \\
\hline Tekanan darah & 0.040 & 1.5 & $1.1-2.2$ \\
Umur & 0.026 & 2.1 & $1.1-4.2$ \\
\hline
\end{tabular}

Sumber: Data Diolah

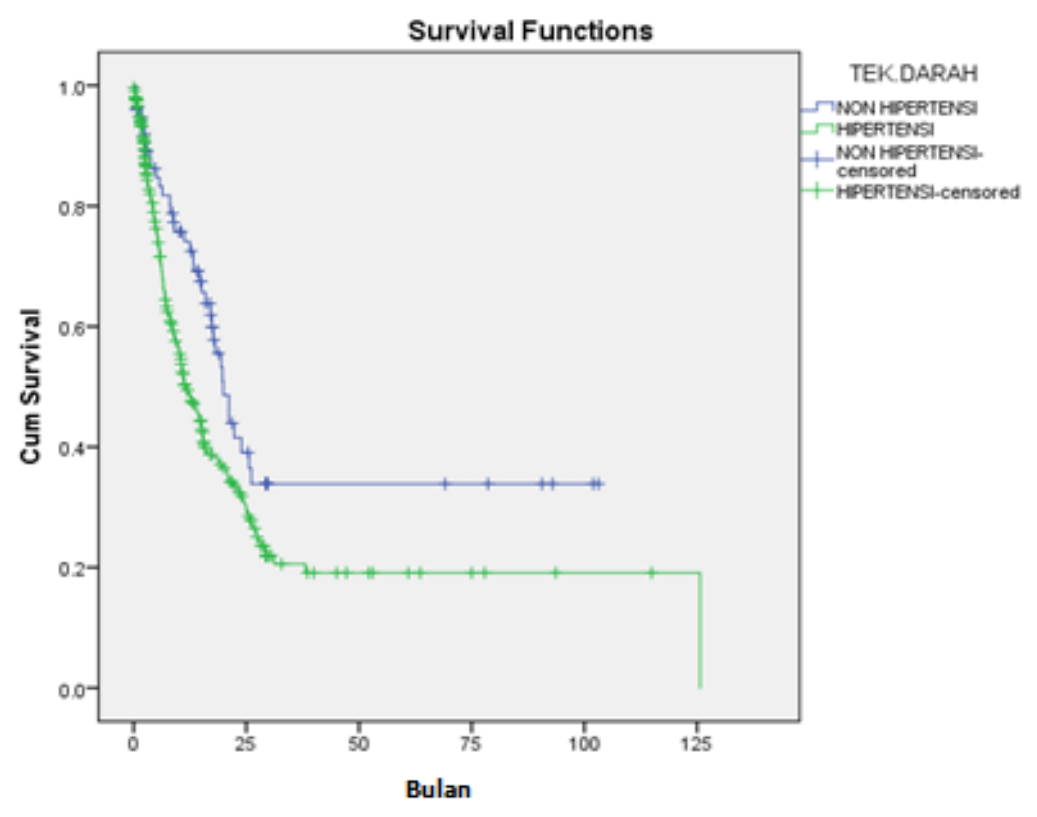

Sumber: Data Diolah

Gambar 2

Grafik Kaplan Meier Ketahanan Hidup Pasien Hemodialisis 
diderita dalam waktu lama akan menyebabkan nefrosklerosis, kemudian berlanjut menjadi kerusakan glomerulus dan atrofi tubulus hingga seluruh nefron rusak dan berdampak pada gagal ginjal (Yulianto, Basuki and Widodo, 2017). Penyakit ginjal kronik dapat menyebabkan naiknya ukuran tekanan darah, begitu pula sebaliknya hipertensi dalam jangka waktu lama juga dapat mengganggu fungsi kerja ginjal. Keterbatasan pada penelitian ini adalah sulit untuk membedakan keadaan status pasien antara penderita penyakit hipertensi lebih dulu atau penderita penyakit ginjal kronik dulu yang terjadi. Selain itu, keterbatasan informasi responden pada lembar rekam medis yang tertulis di dalamnya. Pengaruh hipertensi pada ginjal tergantung dari ukuran tingginya tekanan darah dan lamanya waktu menderita hipertensi. Semakin tinggi tekanan darah seseorang dan diderita dalam waktu lama, maka berakibat pada semakin berat komplikasi penyakit yang mungkin dapat ditimbulkan.

Sejalan dengan hasil penelitian dan laporan nasional IRR menyebutkan bahwa pasien hemodialisis didominasi oleh jenis kelamin laki-laki pada kisaran angka 56$60 \%$. Penelitian Sulistiowati dan Idaiani menyebutkan laki-laki memiliki risiko 2.97 kali lebih besar untuk mengalami PGK (Sulistiowati \& Idaiani, 2015). Penelitian lainnya juga menyatakan hal sama bahwa laki- laki berisiko hingga 2 kali lebih tinggi untuk menderita PGK (p.value $=0.04$ ) (Pranandari \& Supadmi, 2015; Chang et al., 2016). Namun, dalam penelitian Ebad menunjukkan tidak ada hubungan antara jenis kelamin terhadap risiko ketahanan hidup pasien PGK (Ebad, 2018). Perbedaan hasil penelitian ini disebabkan oleh beberapa faktor seperti pengaruh perbedaan hormon reproduksi; gaya hidup seperti konsumsi protein, garam, rokok dan konsumsi alkohol pada laki-laki dan perempuan. Pasien hemodialisis pada penelitian ini didominasi oleh usia di atas 50 tahun sekitar 58.6\%, meski pada data ditemukan juga usia termuda pasien hemodialisis adalah 19 tahun.

\section{SIMPULAN}

Rerata lama hidup pasien hemodialisis dari kelompok hipertensi lebih rendah dibandingkan kelompok non-hipertensi. Pasien hemodilasis dari kelompok hipertensi memiliki risiko kematian lebih tinggi 1,6 kali jika dibandingkan kelompok non-hipertensi. Peneliti menyarankan agar individu dan masyarakat memiliki kemandirian dan kesadaran tinggi untuk melakukan kontrol rutin tekanan darah. Deteksi dini hipertensi sangat dianjurkan dengan memanfaatkan program posbindu yang ada di puskemas dan mengoptimalkan sosialisasi germas (Gerakan Hidup Sehat Masyarakat). Bagi mereka yang

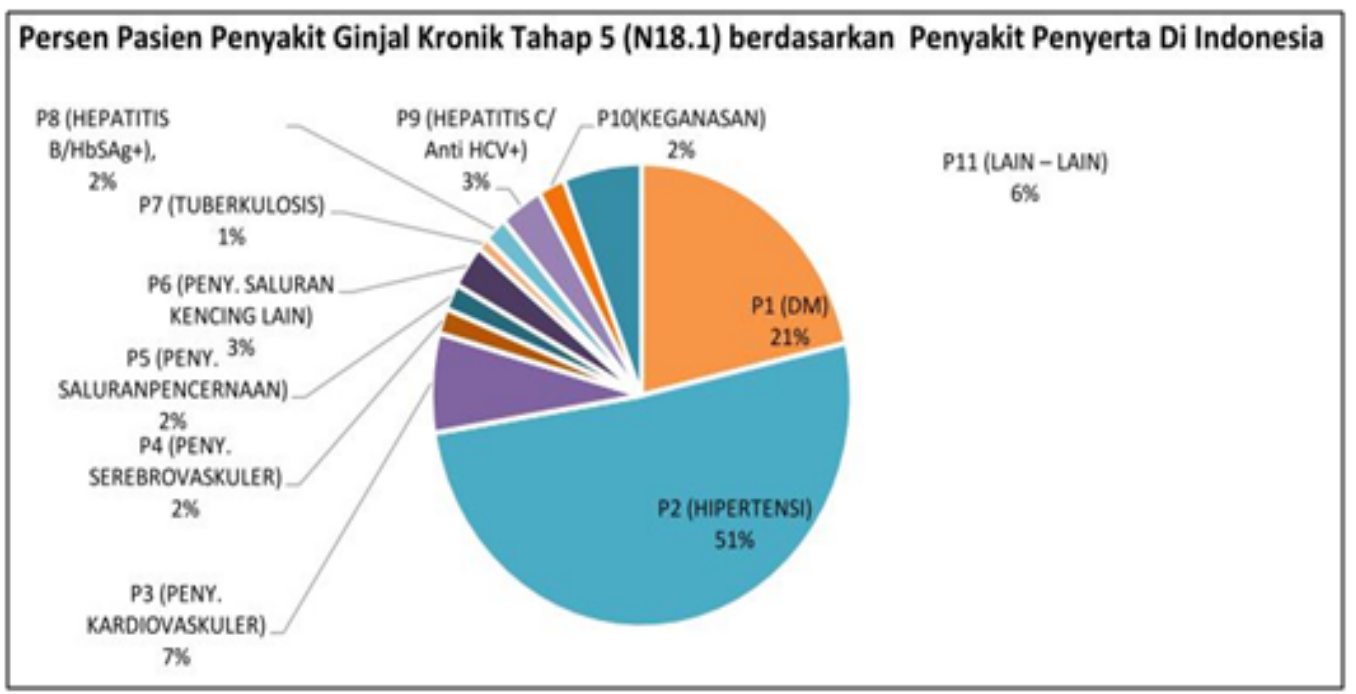

Sumber: Indonesian Renal Registry Team, 2018

Gambar 3

Penyakit Penyerta PGK di Indonesia Tahun 2018 
telah terdiagnosis positif mengalami hipertensi juga disarankan untuk patuh mengonsumsi obat antihipertensi agar tekanan darahnya terkontrol dan berupaya mengubah gaya hidup serta mengendalikan stres. Penelitian lanjutan perlu dilakukan dengan menggunakan data pasien yang lebih akurat terkait status lamanya dan terkontrol tidaknya hipertensi pasien dan faktor penting lainnya seperti gula darah/diabetes.

\section{DAFTAR PUSTAKA}

Badan Penelitian dan Pengembangan Kesehatan (2013) Riset Kesehatan Dasar Riskesdas 2013, Laporan Nasional 2013. Jakarta.

Badan Penelitian dan Pengembangan Kesehatan (2018) Hasil Utama Riskesdas 2018, Kementerian Kesehatan. Jakarta. Available at: https://www.kemkes.go.id/ resources/download/info-terkini/hasilriskesdas-2018.pdf.

Chang, P. Y. et al. (2016) 'Risk factors of gender for renal progression in patients with early chronic kidney disease', Medicine (United States), 95(30). doi: 10.1097/ MD.0000000000004203.

Delima, D. et al. (2017) 'Faktor Risiko Penyakit Ginjal Kronik : Studi Kasus Kontrol di Empat Rumah Sakit di Jakarta Tahun 2014', Buletin Penelitian Kesehatan, 45(1), pp. 17-26. doi: 10.22435/bpk. v45i1.7328.17-26.

Ding, C. et al. (2018) 'The associations of metabolic syndrome with incident hypertension, type 2 diabetes mellitus and chronic kidney disease: a cohort study', Endocrine. Springer US, 60(2), pp. 282-291. doi: 10.1007/s12020-0181552-1.

Ebad, M. (2018) Survival analysis of chronic dialysis patients. University of Waterloo. Available at: http://hdl.handle. net/10012/13584 (Accessed: 31 August 2018).
Eva Sulistiowati and Sri Idaiani (2015) 'Risk Factors of Chronic Kidney Disease Based on Cross-Sectional Analysis Baseline Cohort Study Non-Communicable Diseases at Population 25-65 Years Old n Kebon Kelapa, Bogor 2011', Buletin Penelitian Kesehatan, 43(3), pp. 163172. doi: $10.22435 /$ bpk.v43i3.4344.163172.

Fitrianto, H., Azmi, S. and Kadri, H. (2014) 'Penggunaan Obat Antihipertensi pada Pasien Hipertensi Esensial di Poliklinik Ginjal Hipertensi RSUP DR. M. Djamil Tahun 2011', Jurnal Kesehatan Andalas, 3(1), pp. 45-48. doi: https:// doi.org/10.25077/jka.v3i1.24.

Indonesia Renal Registry Team (2016) 9 th Report Of Indonesian Renal Registry 2016. Available at: https://www. indonesianrenalregistry.org/data/ INDONESIAN RENAL REGISTRY 2016.pdf (Accessed: 31 August 2018).

Indonesian Renal Registry Team (2015) 8 th Report Of Indonesian Renal Registry 2015. Available at: https:// www.indonesianrenalregistry.org/data/ INDONESIAN RENAL REGISTRY 2015.pdf (Accessed: 30 August 2018).

Indonesian Renal Registry Team (2017) 10 th Report Of Indonesian Renal Registry 2017. Available at: https://www. indonesianrenalregistry.org/data/IRR 2017 .pdf.

Indonesian Renal Registry Team (2018) 11 th Report Of Indonesian Renal Registry 2018. Available at: https://www. indonesianrenalregistry.org/data/IRR 2018.pdf. 
KDIGO (2013) 'KDIGO 2012 Clinical Practice Guideline for the Evaluation and Management of Chronic Kidney Disease', Kidney International Supplements, 3(1), pp. 1-150. doi: 10.1038/kisup.2012.73.

Lydia, A. and Nugroho, P. (2018) Kondisi Kesehatan Ginjal Masyarakat Indonesia dan Perkembangannya. Available at: https://www.persi.or.id/images/2018/ data/aida_lydia.pdf (Accessed: 31 August 2018).

Moeloek, N. F. (2018) Air Bagi Kesehatan: Upaya Peningkatan Promotif Preventif bagi Kesehatan Ginjal di Indonesia. Jakarta. Available at: https://www.persi. or.id/images/2018/data/materi_menkes. pdf (Accessed: 31 August 2018).

Muhani, N. and Sari, N. (2020) 'Analisis Survival pada Penderita Gagal Ginjal Kronik dengan Komorbiditas Diabetes Melitus', Media Kesehatan Masyarakat Indonesia, 16(2), p. 216. doi: 10.30597/ mkmi.v16i2.9047.

Nurcahyati, S. (2011) Faktor-Faktor yang Berhubungan dengan Kualitas Hidup Pasien Hemodialisis di Rumah Sakit Islam Fatimah Cilacap dan Rumah Sakit Umum Daerah Banyumas. Indonesia. Available at: http://lib.ui.ac. id/file?file=digital/20282431-T Sofiana Nurchayati.pdf.

Ogston, S. A. et al. (1990) Adequacy of Sample Size in Health Studies., World Health Organization. Chichester: John Wiley \& Sons Ltd.
Pongsibidang, G. S. (2016) 'Risk Factor Hypertension, Diabetes and Consuming Herbal Medicine of Chronic Kidney Disease In Dr. Wahidin Sudirohusodo Hospitals Makassar 2015', Jurnal Wiyata, 3(2), pp. 162-167. Available at: https://ojs.iik.ac.id/index.php/wiyata/ article/view/87.

Pranandari, R. and Supadmi, W. (2015) 'Risk factors cronic renal failure on hemodialysis unit in RSUD Wates Kulon Progo', Majalah Farmaseutik, 22(2), pp. 316-320. doi: https://doi.org/10.22146/ farmaseutik.v11i2.24120.

Stanaway, J. D. et al. (2018) 'Global, regional, and national comparative risk assessment of 84 behavioural, environmental and occupational, and metabolic risks or clusters of risks for 195 countries and territories, 1990-2017: A systematic analysis for the Global Burden of Disease Stu', The Lancet, 392(10159), pp. 1923-1994. doi: 10.1016/S01406736(18)32225-6.

Yulianto, D., Basuki, H. and Widodo (2017) 'Analisis Ketahanan Hidup Pasien Penyakit Ginjal Kronis Dengan Hemodialisis Di RSUD Dr. Soetomo Surabaya', Jurnal Manajemen Kesehatan Yayasan RS.Dr. Soetomo, 3(1), p. 96. doi: 10.29241/jmk.v3i1.92. 